\title{
T7 Vertebra
}

National Cancer Institute

\section{Source}

National Cancer Institute. T7 Vertebra. NCI Thesaurus. Code C33729.

The seventh thoracic vertebra counting from the top down. 